UDC 338.48-44(1-21)

\title{
GEOGRAPHICAL AND LOGISTIC ASPECTS OF URBOTOURISM SUSTAINABLE DEVELOPMENT UNDER THE CONDITIONS OF OVERTOURISM EXTENSION
}

\author{
Ihor Smyrnov
}

Doctor of Geographical Sciences, Professor; ORCID: 0000-0002-6395-7251; e-mail: Smirnov_IG@ukr.net Kyiv National Taras Shevchenko University, Kyiv, Ukraine

\begin{abstract}
A new phenomenon in tourism in the early 21 st century is overtourism, which reflects the acute nature of the problem of managing growing tourist flows, especially in urban areas. The increasing number of urban tourists increases the consumption of natural and tourist resources of cities, exerts socio-cultural influence and exerts pressure on urban infrastructure. Therefore, for urban tourism, it is now an important task to effectively manage the flow of tourists in cities to ensure the sustainability of integrated urban development.

Strategies, measures and proposals for sustainable urban tourism development include mandatory consideration of logistical and socio-geographical (regional) features of urban tourist destinations.
\end{abstract}

Keywords: urban tourism; overtourism; sustainable development of tourist destinations; logistics and tourist aspects of urbotourism

\section{Formulation of the problem}

Recently the term "overtourism" has appeared in the tourism literature, which reflects the acute nature of the problem of managing growing tourist flows, particularly in urban destinations. Today, more than half of the world's population is already living in cities, by 2050 this figure will reach $70 \%$. The increasing number of urban tourists increases the consumption of natural and tourist resources of cities, exerts sociocultural influence and increasing pressure on urban infrastructure. Therefore, for urban tourism, it is now an important task to effectively manage the flows of tourists in cities to ensure the sustainability of integrated urban development. The need for reconciling urban tourism with urban development is indicated by the "New UN Urban Development Program", which outlines 17 goals for their sustainable development. Strategies, measures and proposals to ensure the sustainable development of overtourism and urban tourism include mandatory consideration of logistical and socio-geographical (regional) features. 


\section{Analysis of recent research and publications}

The relevance of this topic is confirmed by the study "Overtourism? Understanding and Managing Urban Tourism Growth Beyond Perceptions", commissioned by UNWTO and based on analysis of data from 8 European cities (Amsterdam, Barcelona, Berlin, Copenhagen, Lisbon, Munich, Salzburg, Tallinn) by experts from the Center for the Recreation, Tourism and Hospitality Expertise of University of Brad (Netherlands), European Tourism Institute of the Future of University of Stenden (Netherlands), with the support of the European Tourism Association and city authorities of respective cities. The perception of tourism and tourists by residents of European cities has been evaluated and Program of strategies (11) and measures (68) has been developed to prevent over-concentration of tourist flows in European cities. Their content was first disclosed in Ukraine in a recent publication by the author (Smyrnov, 2019).

\section{The main material presentation}

The dynamic development of urban tourism in the conditions of overtourism, which is now observed in the world, causes a number of problems, among which one can note the tourist overloading of cities, especially their central and historical sites; destruction of many historical and architectural sites and monuments; increasing of urban waste, including tourist waste; cases of intimate tourism; non-compliance with tourist safety rules in the areas of their accommodation and food with tragic consequences, etc. The connection with logistics (logistical aspect) is evidenced by using in overtourism and urban tourism context such terms as: tourist flow and its characteristics, in particular, magnitude, dynamics, rhythm, density, concentration and dispersion; capacity of tourist destination (one-time, daily, monthly, seasonal, annual); capacity of hotel base (number of placements, total and by category, capacity seasonal and annual); capacity of the restaurant base (number of seats, total and by categories, capacity seasonal and annual); transport and tourism potential (length of transport routes, including by modes of transport, quality of transport routes, including by categories, the density of transport routes, including by transport modes, capacity of transport infrastructure, by type of transport). At the same time, each term of overtourism has a socio-geographical (regional) dimension, that is, local differences, which require mandatory consideration in these logistic strategies and activities.

Therefore, urban tourism is becoming more and more popular in Ukraine and in the world today. It has its own peculiarities due to the high concentration of tourists in the limited area of cities, especially in their central and historical parts. In this connection, there is a problem of increasing the tourist load on the tourism resource base in cities (overtourism), which can lead to its deterioration and degradation. This problem can be solved with the help of a logistical approach to the sustainable development of urban tourism (Smyrnov, 2009). The attention to this problem in the scientific literature is still insufficient, although in the practical management of urban tourism development this problem is already well known and reflected in the development and adoption of relevant documents, for example, in Lviv, where the "Concept of tourism decentralization" was recently adopted within "Strategy for the development of 
tourism in the city until 2021" (Smyrnov \& Liubitseva, 2019). In particular, this concept involves the use of intangible cultural heritage in the course of tourist "unloading" of Lviv center (Market Square and Svobody Avenue) by 1) creating a "second center" of the city through more active involvement in tourism of Shevchenko Avenue with M. Hrushevsky Square (interesting objects here - the monument to M. Hrushevsky, the old building of the Lviv University (so-called "Habsburg University", now houses of geological and biological faculties of Ivan Franko LNU), the cafeteria "Shkotska" (Scottish - nowadays a restaurant), connected with activities here in the pre-war period of so-called Lviv "Mathematical School" under the leadership of S. Banah and S. Ulam; 2) expansion of the tourist territory of the city at the expense of peripheral sections - Sykhiv, Mayorivka, Lewandivka etc. (a guidebook "Tourist Sykhiv" is published); 3) launching "Lviv +" excursion with visits to towns close to Lviv, such as Zhovkva (former royal residence) and Drohobych (the home of the famous artist Bruno Schultz and the oldest salt works in Ukraine). We can add that the attention is paid too to the development of tourism in the city center but the requirement of its tourist unloading is fulfilled by a) development of an underground tourist route from Kornyakt Tower to I. Pidkova Square with the creation of underground city museum and restaurant in the underground of Town Hall; b) the opening of a new tourist route "Lviv Roofs" with visits to recently created restaurants on the top floors of the buildings on the Market Square ("Galicia's Highest Restaurant" and "Very High Cuisine Restaurant" - these conceptual establishments create a modern page of Lviv gastronomy development and belong to the well-known restaurant concern "IFEST").

In addition to the above material, we add that in Lviv it was planned to create a whole underground camp for tourists. Local MPs approved the Detailed Territorial Plan, which envisages the transformation of urban dungeons into tourist routes. But before that, the authorities of Lviv want to find out all the nuances of property rights to underground spaces and their suitability for walking. It is also already known that some of the dungeons need financial investments, as they need to be properly equipped and made safe for tourists. Lviv deputy mayor reported about these plans to the media: "Several underground routes are already in operating as excursion routes. Now it is about the next stage when other routes will be opened. But before doing this, some research should be done, for example, to take soil samples to determine its stability and so on. Also, the city is actively working on the creation of an underground museum of the city, which will have enough basements for excursions. It is also planned to conduct underground excursions under the most iconic monuments of Lviv, such as the Kornyakt Tower, the Dominican Cathedral, the Italian Courtyard, the Town Hall, the Rynok Square, Ivan Pidkova Square, St. Peter and Paul Church. In this case, individual sections of the underground route will get their names, it is possible that for the "underground" tourists will be created their information center and guides will work at these locations. Work will be done to strengthen the tourist trails, arrange ventilation, etc. so that tourists will be as comfortable and safe as possible. It will take about 5 years to complete the entire $800 \mathrm{~m}$ underground route, and the first phase will take about 1 year to complete. There are now separate underground locations in some churches, under the Town Hall on Rynok Square, so the goal is to connect them all in one route. The demand for underground excursions is projected to go wild, and 
the excursions themselves will be by groups. Each guide can take an underground walk with up to 15 people. The practice has shown that there are many tourists who want to visit urban dungeons. By the way, excursions to the roofs of Lviv houses (they cost from 100 to $600 \mathrm{UAH}$ ) were an innovation, while underground excursions will be the next highlight for tourists. The residents believe that such excursions will be interesting for the citizens of Lviv as well.

Let's add, that visiting underground monuments is widespread in the world and has a huge success among tourists. For example, the underground city of Cappadocia in Turkey is included in the UNESCO World Heritage List, dating back to the 1 st century B.C., and the UK has Burlington, an underground bunker city built by the government for a case of a nuclear war with hospital, church and even a pub. In Portland (USA) tourists can visit the Shanghai Tunnels, an underground system of roads paved near town part of Chinatown, with subways leading from the port to hotels and restaurants to deliver goods faster. But many people lived there permanently. There is an underground city in France, and it's Naur, built in the 19th century, which could accommodate up to 3,000 people. This city is located at a depth of $33 \mathrm{~m}$ and a total length of underground corridors - $2 \mathrm{~km}$ (Serov, 2019).

An urgent need in Lviv is to ensure the complete recycling of the total amount of urban waste, including tourist waste from restaurants and cafes too. It should be noted that the daily volume of waste in Lviv is 600 tons. Not surprisingly, Lviv's tourist record ( 2.6 million tourists in 2017 - the first place among Ukrainian cities) coincided with the "waste crisis" in this city. To solve this problem, Lviv is building a most modern waste proceeding plant in Ukraine. At the same time, in November 2018, local authorities restricted the use of plastic bags, and from April 9, 2019, a three-month educational company "Polyethylene-free" was launched in the city, according to which Lviv stores abandoned plastic bags, offering buyers alternative packaging. Lviv restaurants and cafes also use environmental and social approaches in their activities, including waste collection, reuse and recycling. So, a public organization "Tarilka" (Plate) was recently set up in Lviv, and it will propose unused meals and products from supermarkets, restaurants and cafes for homeless people. Such experience was borrowed from Germany. According to the State Statistics Service of Ukraine, Ukrainians annually emit approximately $7 \mathrm{mln}$ tons of usable products worth UAH 5.5 billion. According to the waste amount, Ukraine ranks 9th in the world ranking, overtaking Germany or France, whose population is $1.5-2$ times more. However, when some people throw away good products, others have nothing to eat. The non-governmental organization will collect food at various establishments and distribute food to the homeless - volunteers who collect food from supermarkets and restaurants every day will do so.

The Leopolis Hotel, the Kumpel, Bachevskikh restaurants, the Rukavichka, and Blizenko supermarkets supported this social project in Lviv. Today "Tarilka" is looking for stellar and refrigerated storage to distribute food to homeless people, where the kitchen and dining area will be also. The mayor of Lviv A. Sadovyi promised help to this social project, because he sees prospects in this project. Some restaurateurs privately told the "Vysoky Zamok" newspaper, that they are practicing waste-free production, so they have no food remains. In spite of this, they also support the initiative of the public organization "Tarilka" (Derkach, 2019). 
Another problematic aspect of urban tourism in conditions of overtourism was warned by American experts who assisted in the development of the "Lviv Tourism Concept": as soon as the city's tourism becomes dynamic and massive, among the guests of the city will appear those especially interested in intimate services (Derkach, 2019). What's the connection with logistics there? If there is less advertising from the side of the relevant establishments (night clubs, gentlemen's clubs, show bars, strip bars, etc.), the corresponding tourist flows will decrease.

In contrast to intimate tourism, Lviv has been actively developing conference tourism and blogging tourism for the last several years. In 2018 alone, 430 business events were held in the city, among them important international conferences, attended by about 100,000 participants, $11 \%$ of them foreigners and $82 \%$ from Ukraine. Conference tourism is very advantageous for the city of Lviv because one participant spends \$ 414 a day, accommodating participants in four-star and five-star hotels. Lviv was the first in Ukraine to set up a conference bureau in 2013.

In 2018 conference tourists spent almost UAH 900 mln in Lviv, including catering establishments earned UAH $206 \mathrm{mln}$, and business delegates spent UAH $150 \mathrm{mln}$ for leisure and entertainment, and another $131 \mathrm{mln}$ - for accommodation. The direct economic effect of this type of tourism amounted to UAH $775 \mathrm{mln}$ in 2018, taxes were paid $188 \mathrm{mln}$ UAH. At the same time 5.8 thousand people work in Lviv's conference industry. What Lviv lacks, are large conference halls for 5,000 participants, such as in Krakow and Poland. So there is a demand for international-level conference hotels. Then conference tourism would bring even greater profits and dividends to the city of Lviv.

Another recent trend in attracting tourists to Lviv, including foreigners, is to seek services of travel bloggers. "Availability, romance-atmosphere and price-quality ratio. The exquisite city looks like a traditional European capital, completed with cobbled streets, classical music festivals and high-profile literary festivities" - in such a way expert of the leading American newspaper "The Washington Post" describes the city of Lviv. That's for the first time the leading world edition wrote about Lviv. In recent years, travel bloggers have been travelling to Lviv to promote the city. Each year the city of Lviv is in the top rankings of the world and European cities worth to go on weekends or holidays. According to the head of the tourism department of Lviv city council, it is exactly tourism blogs that give Lviv more and more guests from all over the world. As a journalist wrote, his colleagues see the article's rating and come to explore the city even better. When a city is recognized, its name is capitalized for investment and investors who want to start a business come here. Therefore, there are many benefits from travel bloggers. One of them is a wide international promotion of Lviv. The locals themselves are also pleased to hear about their city in the world. Recently one of the Polish tourist sites wrote about Lviv. Polish experts focused on the city's emotional establishments - concept restaurants and cafes. They say it adds special charm to the city. Each restaurant has its own legend. Poles also point out that it is more interesting for people of old age to visit the Lychakiv Cemetery, but young people have other priorities - individual tours by the center. Our neighbors also notice "friendly prices" in shops, souvenir shops, cafes. It is noted that a good weekend can be spent here as there are direct flights from Gdansk to Lviv with ticket 
prices from 500 to 1200 UAH. A blogger from Irish Dublin came to Lviv on the eve of Easter 2019. It was Ryanair's airline manager who wrote blogs about all the cities Dublin has direct flights to. He made videos about Lviv, studied its architecture and cuisine, as well as traditions. He arrived just before the holidays and saw the whole process of cooking, painting Easter eggs, and wadding. He visited Shevchenko Park and liked embroideries and kitchen there. Accordingly, his review article about Lviv is expected to be quite prestigious. Let's note that some travel bloggers call crazy amounts in Euro for their services. But Lviv works with them according to another scheme, when the city agrees with the business and, accordingly, the hoteliers rent bloggers for free, restaurants feed them free, the owners of tourist companies show the city free. Therefore, bloggers enthusiastically describe the tourist attractions of the city of Lviv and it does not cost too much. At the same, time each blogger has its target audience, so its readers come to the city. For example, there are restaurant bloggers or hotel bloggers and there are bloggers, writing about literature and culture, so separate tour is formed for each blogger.

Another important problem is the need for increased security requirements for urban tourists. The main components of the solution to this problem are a) development of increased requirements for the safety of tourists in the conditions of overtourism, especially in terms of their accommodation and food; b) constant and strict control of the security of the living conditions of tourists, especially in apartments and private apartments; c) tight security control in the field of tourist food, with particular attention to the functioning and serviceability of the equipment of "street food" points in popular tourist locations; d) control of urban tourist transport, including tourist buses, sightseeing "trains", tourist coaches etc.

It should be noted that the Lviv authorities have already taken into account these proposals, so, since 2019, the mayor of Lviv has a deputy for security, who has under responsibility departments of waste management, emergency management, civil protection of population and city security management.

\section{Conclusions}

Thus, the dynamic development of urban tourism in the conditions of overtourism, which is now observed in Ukraine and the world, causes several, among which one can note the tourist overloading of cities, especially their central and historical sites; destruction of many historical and architectural sites and monuments; increasing of urban waste, including tourist waste; cases of intimate tourism; non-compliance with tourist safety rules in the areas of their accommodation and food with tragic consequences, etc. Most of these problems can be solved on the basis of geographical and logistical aspects of overtourism in cities. Accordingly, the geologistical approach proposed, in particular in the Concept of "Tourism Decentralization of Lviv", should be extended to all other aspects of the tourism industry of the city, including waste management, use of the latest technologies and attraction of national and international investments. These recommendations apply not only to Lviv but also to other cities - significant tourist centers of Ukraine - Kyiv, Odesa, Kharkiv, Dnipro, etc. 


\section{References}

Derkach, M. (2019, October 10-16). Smachna "Tarilka" dlia bezkhatkiv [Delicious "Plate" for the homeless]. Vysokyi Zamok, p. 9 [in Ukrainian].

Ivanova, E. (2018). 50 ottenkov Lvova [50 shades of Lviv]. Novoe vremya strany, 19, 38-41 [in Russian].

Serov, I. (2019, September 23). Vo Lvove okroyut vse podzemelya [All dungeons will be opened in Lviv]. Segodnya, p. 5 [in Russian].

Smyrnov, I.H. (2009). Lohistyka turyzmu [Tourism logistics]. Kyiv: Znannia [in Ukrainian].

Smyrnov, I.H., \& Liubitseva, O.O. (2019). Marketynh staloho turyzmu [Marketing of sustainable tourism]. Kyiv: Lira-K [in Ukrainian].

Smyrnov, I.H. (2019). Kontseptualni zasady stratehii staloho rozvytku urboturyzmu v umovakh overturyzmu [Conceptual bases of the strategy of sustainable development of urban tourism in the conditions of overtourism]. In Ekonomika, oblik, finansy ta pravo $v$ umovakh hlobalizatsii: tendentsii ta perspektyvy [Economy, accounting, finance and law in the context of globalization: trends and prospects], Collection of abstracts of reports of the international scientific-practical conference (pp. 65-70). Poltava: TsFEND [in Ukrainian].

World Tourism Organization. (2018). Overtourism? Understanding and Managing Urban Tourism Growth Beyond Perceptions. Madrid: UNWTO. Retireved from https://www.e-unwto.org/ doi/pdf/10.18111/9789284420070 [in English].

\section{2 ГЕОГРАФІЧНІ ТА ЛОГІСТИЧНІ АСПЕКТИ СТІЙКОГО РОЗВИТКУ УРБОТУРИЗМУ ЗА УМОВ ПОШИРЕННЯ ОВЕРТУРИЗМУ}

\section{Ігор Смирнов}

Доктор географічних наук, професор; ORCID: 0000-0002-6395-7251; e-mail: Smirnov_IG@ukr.net Київський національний університет імені Тараса Шевченка, Київ, Україна

\section{Анотація}

Новим явищем в туризмі на початку XXI ст. стає овертуризм, який відображає гостру суть проблеми управління зростаючими туристичними потоками, особливо у міських напрямках. Зростаюча кількість міських туристів збільшує споживання природних та туристичних ресурсів міст, чинить соціокультурний вплив та посилює тиск на міську інфраструктуру. Тому для міського туризму зараз важливим завданням $€$ ефективне управління потоками туристів у містах для забезпечення стійкості інтегрованого міського розвитку.

Стратегії, заходи та пропозиції щодо забезпечення сталого розвитку міського туризму включають обов'язкове врахування логістичних та соціально-географічних (регіональних) особливостей міських туристичних дестинацій.

Ключові слова: урботуризм; овертуризм; стійкий розвиток туристичних дестинацій; логістичні та туристичні аспекти урботуризму 